BULLETIN (New Series) OF THE

AMERICAN MATHEMATICAL SOCIETY

Volume 46, Number 4, October 2009, Pages 669-670

S 0273-0979(09)01269-5

Article electronically published on July 7, 2009

\title{
ABOUT THE COVER: CHRISTOPHER CLAVIUS, ASTRONOMER AND MATHEMATICIAN
}

\author{
GERALD L. ALEXANDERSON
}

As early as 1232 John of Holy Wood, an English astronomer known usually by the Latin translation of his name, Sacro Bosco, observed that the Julian calendar was becoming increasingly inaccurate over time. It wasn't until roughly 300 years later that Christopher Clavius, a German Jesuit, formulated the improved Gregorian calendar that was adopted by Pope Gregory XIII and instituted on Friday, October 15,1582 .

This is the astronomical work for which Clavius is best known but he was a polymath who wrote on various branches of science and mathematics. Born in 1538, two years before St. Ignatius Loyola's Society of Jesus was approved by the Catholic Church, Clavius became one of the earliest members of the Order that would have considerable influence on the history of astronomy and mathematics, particularly in the 16th and 17th centuries. The title page shown on the cover, with its armillary sphere, is from one of Clavius's most important works, the In Sphæram Ioannis de Sacro Bosco Commentarius (Rome, 1570), which not only presented the much earlier work of the 13th century Sacro Bosco but included evidence of Clavius's awareness of the Copernican theory as described in the De Revolutionibus Orbium Coelestium of 1543 (though Clavius remained loyal to the theory of Ptolemy). It also provides evidence of Clavius's long time correspondence with Galileo, in which at one point he provided confirmation of some of Galileo's calculations on Venus and Saturn. Galileo was sick in bed when he received Clavius's confirming data and J. MacDonnell pointed out that "the letter brought him so much joy, it occasioned his immediate recovery" [1]. During that period Clavius was also corresponding with Viète and Kepler.

As an author of scientific treatises as well as textbooks widely used in Jesuit schools, he was influential in introducing notation or promulgating that of others; e.g., the decimal point, the radical, applications of logarithms, and parentheses to group together algebraic symbols. His books were on topics in astronomy, spherical geometry and practical geometry, on Euclid (where he called attention to the problem involving the fifth postulate), as well as practical arithmetic. George Sarton referred to Clavius as "the most influential teacher of the Renaissance". His reputation in science prompted the forming of the Clavius Mathematics Group in 1963, an organization of lay and religious mathematicians who organize four-week research meetings each summer in settings on campuses as widespread as Georgetown, the IAS at Princeton, McGill, Notre Dame, UC Berkeley, and the IHES outside Paris, among others.

Received by the editors May 10, 2009.

(C)2009 American Mathematical Society Reverts to public domain 28 years from publication 
Clavius the teacher argued powerfully and successfully for the inclusion of mathematics in the Jesuit Ratio Studiorum that set the educational goals of instruction in Jesuit schools. In mathematics, he prescribed "the study of Euclid ... and ordered a monthly presentation by some student of 'some famous mathematical problem' and a defense of his solution" 2. It appears as if Clavius may well have been ahead of his time. For more examples of Clavius's influence on mathematical teaching early in the scientific revolution, see $[\underline{3}$.

Clavius was not alone among members of the Society of Jesus who contributed to mathematics; others were Ceva (of cevians in geometry), Roger Boscovich (so admired in his native Croatia that his portrait appears on Croatian currency), Athanasius Kircher (who wrote 39 large volumes of scientific writings), Girolamo Saccheri (who probably came close to "discovering" noneuclidean geometry), and many more. Thirty-five Jesuit scientists have had craters of the moon named for them, based on their discoveries. This list includes Clavius and led to a surprising query a few years ago. An East Coast Jesuit university in 1987 honored Jesuit scientists by naming buildings for them in a housing complex on campus: Boscovich, Clavius, Kircher, Matteo Ricci, and Christopher Scheiner. This led to an inquiry from a governmental agency: "Why are you naming dormitories on your campus for craters of the moon?"

\section{REFERENCES}

1. Joseph MacDonnell, S.J., Jesuit geometers: A study of fifty-six prominent Jesuit geometers during the first two centuries of Jesuit history. With a foreword by John W. Padberg. Studies in Jesuit Topics. Series IV, 11. Institute of Jesuit Sources, St. Louis, MO; Vatican Observatory Publications, Vatican City, 1989, p. 53. MR.1108623 (92e:01082)

2. Dennis C. Smolarski, S.J., The Jesuit Ratio Studiorum, Christopher Clavius, and the Study of Mathematical Sciences in Universities. Science in Context (Cambridge U. Press) 15(3) (2002), 447-457. MR2077134 (2005e:01010)

3. Dennis C. Smolarski, S.J., Teaching Mathematics in the Seventeenth and Twenty-first Centuries. Math. Mag. 75(4) (2002), 256-262. MR2074191

Department of Mathematics and Computer Science, Santa Clara University, Santa Clara, California 95053-0290

E-mail address: galexand@math.scu.edu 